\title{
LIETUVIŠKOS IR TARPTAUTINĖS RINKOS EKONOMIKOS IR INFORMATIKOS TERMINIJŲ INTEGRACIJA
}

\author{
Elvyra Vida Tadauskiené
}

Vilniaus universitetas, Universiteto g. 3, LT-01513 Vilnius

Straipsnyje nagrinejjama lietuviškos ir tarptautinès rinkos ekonomikos ir informatikos terminiju integracijos büdai bei ju priežastys. Terminijos atsiradimą lèmè istorinès aplinkybès, t. y. ekonominiu ryšiu su kitomis valstybèmis pletra. Ekonomikos ir informatikos terminijos integracijos problema iškyla verčiant tarptautinius žodžius ị lietuvių kalba, kai naudojame panašius lietuviškus pakaitus ar skolinius. Kadangi skoliniai dar nèra visiškai perimti, pirmenybè teikiama lietuviškiems atitikmenims.

Reikšminiai žodžiai: lietuviška ir tarptautinè rinkos ekonomikos ir informatikos terminija, lietuviškas atitikmuo, pakaitas, daugiareikšmès, naujadaras, svetimybė, skolinys, integracija, integruoti.

\section{Ivadas}

50 metų vartojome rusišką ekonomikos terminiją arba rusiškų terminų lietuviškus atitikmenis. Buvo paplitę rusiški ekonomikos terminai su lietuviška galūne. Tuometinę rusišką sovietinę ekonomiką ir jos terminiją skurdino jos ribotumas. Anuomet Lietuvoje nebuvo laisvosios rinkos ekonomikos ir jos terminijos, nes nebuvo pačios rinkos. Ūkinèje veikloje viešpatavo komandinè skirstymo ekonomika su savo terminija. Nebuvo ir šiuolaikinès informatikos, kuri, kaip ir rinkos ekonomika, perimta iš Vakarų su jau susiformavusia tarptautine vakarietiška, dažniausiai - angliška, terminija. Iš pradžių imta vartoti tarptautinius terminus su lietuviškomis žodžių galūnėmis ir net be jų.

Lietuvai atkūrus nepriklausomybę, daug nuveikta tvarkant lietuvišką ekonomikos ir informatikos terminiją, ji pritaikyta prie tarptautinès terminijos. Išleista žodynų, kurie turejjo padèti ieškoti lietuviškų atitikmenų, verčiant tarptautinius terminus ì lietuvių kalbą, kurti naujadarus. Neradus žodynuose lietuviškų žodžių termino turiniui išreikšti, dažnai plinta svetimybès, kurias vartoja tvarkydami dokumentus specialistai, verslininkai, sandorių dalyviai ir kiti žmonès bendraudami. Dažnai vartojamos svetimybès pateikiamos greta adekvačių lietuviškų terminų.

\section{Tiriamojo darbo semantinė analizè}

Tarptautiniai terminai vis dar skverbiasi ị lietuvišką terminiją ir, žinoma, skverbsis toliau. Šj reiškini skatina glaudesni tarptautiniai ryšiai, žmonių bendravimas, informacijos plètra Lietuvoje. Taigi tarptautinès ekonomikos ir informatikos terminijos ekspansija, svetimybių vartojimas yra neišvengiami dalykai ir mezgant ryšius su užsieniečiais, užsienio įstaigomis bei ūkiniais subjektais, ir šalies viduje. Todèl turime nuspręsti, kaip žiūrèsime ị ši reiškinị. Nustatydami pagrindinius lietuviškos tarptautinès rinkos ekonomikos ir informatikos terminijų integracijos būdus bei jų atsiradimo priežastis, remsimès terminų gretinimu bei jų semantine analize lietuvių ir anglų kalbose (Löbner 2003: 3-13). Šiuo klausimu esama dviejų skirtingų nuomonių. 
Siūloma:

1. Leisti lietuviškos rinkos ekonomikos ir informatikos terminijai laisvai plètotis ir integruotis i tarptautinę terminiją ir taip išsaugoti kalbos gyvybingumą. Tai rodo kitų Europos šalių - Ispanijos, Prancūzijos, Italijos pavyzdys. Šiose šalyse nesiekiama nacionalinès terminijos grynumo.

2. Vartoti tik lietuviškus ekonomikos ir informatikos terminus, o svetimybes pripažinti tik tuo atveju, jei tarptautinio termino nèra kuo pakeisti arba jei jis Lietuvoje jau paplitęs; kurti lietuviškus naujadarus, užuot skolinusis „svetimus“ terminus.

Tad kyla klausimas, kas geriau. Rinkos ekonomikos ir informatikos terminais tiksliai ir kuo suprantamiau apibūdinamos ekonomikos ir informatikos kategorijos. Bendraudami su užsieniečiais be tarptautinių terminų, žinoma, neapsieisime. Tarptautiniai terminai skverbiasi i lietuvišką terminiją, verčiant rinkos ekonomikos ir informatikos literatūrą ị lietuvių kalbą. Lietuviškus terminus lengviau suprasti nei svetimybes su prirašytomis lietuviškomis galūnemis. Apie vieną tokị lietuviškos tarptautinès rinkos ekonomikos ir informatikos terminijų integracijos būdą jau rašème. (Tadauskienė 2005: 105-108; 109-112).

Jei esamų lietuvių kalbos žodžių nepakanka, norint tiksliai ir aiškiai apibūdinti tarptautinị terminą, mūsų nuomone, geriau skolintis jị iš tarptautinès terminijos, užuot kūrus lietuviškus, bet ne visada vykusius naujadarus. Šis būdas racionalesnis terminui įsiminti ir vartoti, nes lengviau ìsiminti vieną skolinị negu naujadarą - kurị nors ekonomikos bei informatikos terminą. Problemiškesnis yra skolinių skverbimosi ị lietuvišką ekonomikos ir informatikos terminiją klausimas, nes svetimybès vis dažniau vartojamos greta turimų lietuviškų terminų arba vietoj jų. Žodynai su tokiomis svetimybėmis jau susitaikè - greta lietuviškų terminų pateikiamos ir adekvačios svetimybès. Kaip turètume žiūrèti ị naujų svetimybių atsiradimą ir plitimą lietuviškoje terminijoje? Mūsų manymu, skolinio vartojimas turi būti ribojamas, kol jis dar nespejo prigyti. Oficialioje kalboje ir dokumentuose vartotini lietuviški ter- minai (prireikus greta lietuviško termino galima pateikti skolinį). Jei skolinys prigyja lietuviškoje terminijoje, o tai neišvengiamas procesas, būtų neapdairu ir beprasmiška spyriotis, kovoti su šiuo reiškiniu komandinèmis priemonèmis. Imkime pavyzdžių. Ekonomikos terminijoje prigijo daugybè visiems suprantamų svetimybių ir dèl jų vartojimo abejonių nekyla. Jos integravosi i lietuvišką terminiją, tačiau tai nepadarè žalos lietuviškai terminijai, atvirkščiai - ją praturtino. Tai rodo daugelio naujesnių rinkos ekonomikos ir informatikos terminų - svetimybių vartojimas lietuviškoje terminijoje: marketingas (greta nevykusio turinio naujadaro rinkodara, nes rinkos daryti neimmanoma), akcija, kompiuteris, komercija, aukcionas (greta naujadaro varžytines), magnetola, monitorius, čipas (greta ne visai suprantamo naujadaro lustas), kontraktas (greta lietuviško termino sutartis), šefas, krosambleris, diskas ar diskelis, adapteris, kasetè (magnetofono), modulis, meniu ir kt. Skolinio integravimas i lietuvišką rinkos ekonomikos ir informatikos terminiją tampa problemiškas, jei jis nevienodai suprantamas: 1) dèl savo daugiareikšmiškumo; 2) pasiskolintai svetimybei igijus bendrinei kalbai būdingą reikšmę. Kol svetimybė dar nespejjo galutinai issitvirtinti lietuviškoje terminijoje, norint išvengti painiavos, ją reikia versti pagal prasmę ar kontekstą. Tai vienas tarptautinès terminijos integravimo ị lietuvišką terminiją būdas. Svetimybès vartojimas greta lietuviško termino, pavyzdžiui, mažai kam suprantamas apibūdinimas digresija (digression) lietuviškai gali reikšti nutolimas arba nukrypimas (nuo svarstomo dalyko, gvildenamo klausimo).

Finansu ir informatikos terminas notifikacija, nelygu kontekstas, ekonomistų kalba gali reikšti ir paskelbimas, pranešimas, įspejjimas, registravimas. Todèl vienareikšmis skolinys notifikacija mūsų gali būti netiksliai ir net klaidingai suprastas, nes lietuviškai terminijoje juo apibūdinamos tik tam tikros finansų ir informatikos kategorijos.

Plinta svetimybè diferencija. Angliškai difference reiškia skirtumą. Dažniausiai ši svetimybè taip suprantama lietuviškoje terminijoje. Bet 
tai gali reikšti ir nesutarimą (verslo partnerių), skirtumą (derybų dalyvių nuomonių), ataskaitų, tikrinimo ir apskaitos duomenų nesutapimą, o informatikoje šiuo žodžiu dar apibūdinamas pokytis (skaičiavimo rezultatų, tam tikrų duomenų). Tokiais atvejais patartina kategorijas įvardyti lietuviškais terminais. Jie tikslesni už skolinị dèl skirtingo angliško termino ir skolinio traktavimo pas mus dèl anglų ir lietuvių kalbų žodžių vartojimo skirtumų. Žodis transformacija, kuris reiškia kintamosios elektros srovès įtampos sumažèjimą ar padidejjimą, lietuviškoje technikos terminijoje seniai prigijęs. Dabar informatikos žodynuose randame ir adresų, duomenų, kodo transformaciją (dinaminè, tiesinè, atvirkštinè ir kt.), tai yra jų keitimas, vertimas. Ar ne geriau ši procesą apibūdinti lietuviškais žodžiais, užuot vertus spèlioti, ką šis elektrotechnikos terminas galètų reikšti.

Testavimą (angl. testing) paprastai suprantame kaip (iš)bandymą, pagal kurị nustatomas tikrinamo asmens sugebejimas, savybès. Dabar ši svetimybė braunasi i informatikos terminiją, ja apibūdinamas rinkmenos, modelių, programos, duomenų, ciklo, baitų tikrinimas. Vartojant šią svetimybę vietoj lietuviško termino, neišvengiamai kyla asociacijų su, pavyzdžiui, specialistų testavimo metodika.

Priešdèlis de anglų kalboje dažniausiai reiškia ko nors pašalinimą, panaikinimą. Tačiau tarptautinejje informatikos terminijoje terminu deblocking vadinamas ir blokų atskyrimas. Pavadinus ši veiksmą deblokavimu, galima suklaidinti.

Ne visi supras, ką reiškia selektyvusis įrašas (selective recording), kalbant apie atrankinị ịrašymą. Selektyviąą programą geriau vadinti atrankine programa.

Abejonių kelia ir svetimybès produktas (angl. product) vartojimas informatikos terminijoje, jei turima galvoje sandauga (modulinè, skaliarinè, tarpinè, loginè ir pan.), užbaigtas darbas, užsakymas arba gaminys, nes produktą lietuviai ekonomikoje supranta kaip maistui skirtą gaminị (pavyzdžiui, maisto produktai). Ar verta vadinti produktais, pavyzdžiui, metalo, gelžbetonio gaminius, dirbinius?

\section{Išvados}

Lietuviškos tarptautinès rinkos ekonomikos ir informatikos terminai integruojami dvejopu būdu:

1) tarptautiniai terminai verčiami ị lietuvių kalbą parenkant tapačius tarptautiniams lietuviškus terminus;

2) iš tarptautinès terminijos pasiskolinami ir adaptuojami ekonomikos ir informatikos kategorija (dalykai ir reiškiniai) apibūdinantys užsienio kalbų žodžiai.

Integracijos procesus spartina tarptautinių mokslo, verslo ryšių, žmonių judejjimo tarp šalių ir informacijos srautų intensyvejjimas, būtinybė vartoti tarptautinių terminus greta lietuviškų terminų arba juos pakeisti skoliniais. Tai dèsninga ir racionali lietuviškosios rinkos ekonomikos ir informatikos terminijos raida. Toks integravimas nèra smerktinas, nes laužo kalbų barjerus, nebūtina specialiai mokytis tarptautinių ir lietuviškų tų pačių kategorijų pavadinimų, lengviau susikalbèti ịvairių šalių specialistams, (verslininkams, valdininkams) interneto ir kitų informacijos priemonių vartotojams. Kol skolinys nepradètas visuotinai vartoti, būtina ieškoti atitinkamų terminų lietuviškų pakaitų ir vartoti juos dokumentuose, spaudiniuose bei oficialiojoje kalboje. Tai būtina daryti dèl šių priežasčių: 1) kai kurie tarptautiniai terminai, kilę iš užsienio (dažniausiai - anglų) kalbos, nelygu kontekstas, yra daugiareikšmiai; 2) kai kurie tarptautinių terminų pavadinimai tèra sutartiniai žodžiai, kurie bendrinejje kalboje reiškia visai ką kita; 3) daugeliui ekonomikos ir informatikos terminų turime tapačių tarptautiniam terminui, tačiau skirtingos reikšmès žodžių, kurie tiksliau nei vienareikšmis terminas apibūdina konkretų dalyką arba reiškinị. Jei neturima tarptautinio rinkos ekonomikos ar informatikos termino tinkamo lietuviško atitikmens, geriau įsileisti svetimybę, užuot kūrus ir diegus lietuviškoje terminijoje išsigalvotą naujadarą. Lietuviškoje terminijoje priimtini ir jau prigiję bei visiems suprantami tarptautinių terminų skoliniai. Keisti juos ị lietuviškus nederètų. Skoliniai turi būti 
vartojami lietuviškoje rinkos ekonomikos ir informatikos terminijoje paisant lietuvių kalbos bei žodžių darybos vartojimo taisyklių (pridedamos lietuviškos galūnès, priešdèliai).

\section{Literatūra}

Löbner, S. 2003. Semantik. Eine Einführung. Walter de Gruyter. Berlin. New York.
Tadauskienè, E. V. 2005. „Informatikos ir ekonomikos terminijos panašumai ir skirtumai“, Filologija 13: $105-108$.

Tadauskiene, E. V. 2005. „Informatikos terminijos ypatumai ir problemos", Filologija 13: 109-112.

Valatkaite, R.; Kudirka, Z. 1977. Lietuvių-anglųrusų-vokiečiu kalbų terminų žodynas. Vilnius: Matematikos ir informatikos institutas.

\title{
INTEGRATION OF ECONOMICS AND INFORMATION TERMINOLOGY INTO THE LITHUANIAN AND INTERNATIONAL MARKET
}

\author{
Elvyra Vida Tadauskienè
}

The article considers the integration of economics and information terminology into the Lithuanian international market. The occurrence of the terminology was predetermined by the historical conditions, i. e., the expansion of international economical links with foreign countries. Economics and information terminology gets integrated when translating international words into Lithuanian with the help of adequate Lithuanian substitutes or borrowings. As long as the borrowing has not completely taken root, its Lithuanian equivalent is considered to be more preferable.

Keywords: economics and information terminology of the Lithuanian and international market, Lithuanian equivalent, substitute, polysemous, neologism, foreign words, borrowing, integration, integrate.

Iteikta 2006-04-20; priimta 2006-05-16 